\title{
Litsea japonica Leaf Extract Suppresses Proinflammatory Cytokine Production in Periodontal Ligament Fibroblasts Stimulated with Oral Pathogenic Bacteria or Interleukin-1 $\beta$
}

\author{
In-Gyeong Yun ${ }^{1,+(\mathbb{D})}$, Sun-Hee Ahn ${ }^{2,+} \mathbb{( B}^{-}$, Weon-Jong Yoon ${ }^{3}$, Chang Sook Kim ${ }^{3}$, \\ Yun Kyong Lim ${ }^{4}$, Joong-Ki Kook ${ }^{4}$, Seunggon Jung ${ }^{5}$, Choong-Ho Choi ${ }^{1, \ddagger}$ (i) \\ and Tae-Hoon Lee $2,6, *, \ddagger$ (iD \\ 1 Department of Preventive and Public Health Dentistry, Dental Science Research Institute, School of \\ Dentistry, Chonnam National University, Gwangju 61186, Korea; heavenstairs@naver.com (I.-G.Y.); \\ hochoi@chonnam.ac.kr (C.-H.C.) \\ 2 Department of Oral Biochemistry, Dental Science Research Institute, School of Dentistry, Chonnam National \\ University, Gwangju 61186, Korea; sun3193@jnu.ac.kr \\ 3 Jeju Biodiversity Research Institute (JBRI), Jeju Technopark (JTP), Jeju 63608, Korea; \\ yyjkl@jejutp.or.kr (W.-J.Y); cskim@jejutp.or.kr (C.S.K.) \\ 4 Department of Oral Biochemistry, School of Dentistry, Chosun University, Gwangju 61452, Korea; \\ dbsruddl77@hanmail.net (Y.K.L); jkkook@chosun.ac.kr (J.-K.K.) \\ 5 Department of Oral and Maxillofacial Surgery, School of Dentistry, Chonnam National University, \\ Gwangju 61186, Korea; ashgray79@gmail.com \\ 6 Department of Molecular Medicine (BK21plus), Chonnam National University Graduate School, \\ Gwangju 61186, Korea \\ * Correspondence: thlee83@jnu.ac.kr; Tel.: +82-62-530-4842 \\ $\dagger$ These authors contributed equally to this work. \\ $\ddagger$ These authors contributed equally to this work.
}

Received: 19 July 2018; Accepted: 21 August 2018; Published: 23 August 2018

\begin{abstract}
Periodontal disease, a chronic disease caused by bacterial infection, eventually progresses to severe inflammation and bone loss. Regulating excessive inflammation of inflamed periodontal tissues is critical in treating periodontal diseases. The periodontal ligament (PDL) is primarily a connective tissue attachment between the root and alveolar bone. PDL fibroblasts (PDLFs) produce pro-inflammatory cytokines in response to bacterial infection, which could further adversely affect the tissue and cause bone loss. In this study, we determined the ability of Litsea japonica leaf extract (LJLE) to inhibit pro-inflammatory cytokine production in PDLFs in response to various stimulants. First, we found that LJLE treatment reduced lipopolysaccharide (LPS)-induced pro-inflammatory cytokine (interleukin-6 and interleukin-8) mRNA and protein expression in PDLFs without cytotoxicity. Next, we observed the anti-inflammatory effect of LJLE in PDLFs after infection with various oral bacteria, including Fusobacterium nucleatum, Porphyromonas gingivalis, Treponema denticola, and Tannerella forsythia. These anti-inflammatory effects of LJLE were dose-dependent, and the extract was effective following both pretreatment and posttreatment. Moreover, we found that LJLE suppressed the effect of interleukin-1 beta-induced pro-inflammatory cytokine production in PDLFs. Taken together, these results indicate that LJLE has anti-inflammatory activity that could be exploited to prevent and treat human periodontitis by controlling inflammation.
\end{abstract}

Keywords: periodontal disease; inflammation; periodontal ligament; Litsea japonica leaf extract; IL-6; IL-8 


\section{Introduction}

Periodontitis is one of the most common oral infectious diseases; it is an inflammatory disease caused by oral pathogens, which destroy the periodontal ligament (PDL) and alveolar bone with gingival recession [1-3]. The PDL is a fibrous connective tissue between the cementum and alveolar bone surrounding the root; it plays an important role in the maintenance, function, and regeneration of the periodontal tissue, as well as in the regulation of periodontal inflammation [4]. Periodontal tissues are known to be sensitive to lipopolysaccharide (LPS) and other pathogenic factors [5].

Conversion from healthy periodontal status to disease is not caused by a single bacterium, but by bacterial complexes of certain species. For example, Socransky and Haffajee stratified microbial populations into five groups or complexes that appear to co-occur and represent a bacterial consortium associated with the development of biofilm-associated infections, gingivitis, and periodontitis [6-8]. In particular, a bacterial complex named "red complex" that consists of Porphyromonas gingivalis, Treponema denticola, and Tannerella forsythia has been shown to increase in deep periodontal pockets, and is strongly related to the progression of periodontal disease in advanced periodontal lesions [9-11]. In addition, Fusobacterium nucleatum plays a role in the development of periodontitis by acting as a bridge for the interaction of red complex bacteria [12,13]. Recently, we reported the importance of $F$. nucleatum in the periodontal microbial ecology and host response to F. nucleatum [14,15].

Oral bacteria and their components, including LPS, promote the production of pro-inflammatory cytokines in PDL fibroblasts $[4,16]$. Interleukin-6 (IL-6) and interleukin-8 (IL-8) are prominent pro-inflammatory cytokines that are closely related to periodontitis, leading to periodontal tissue destruction and alveolar bone resorption $[17,18]$. These pro-inflammatory cytokines are mainly produced by immune cells, i.e., macrophages and lymphocytes, when they are exposed to inflammatory stimuli [19], and by gingival fibroblasts and the PDL, which functions as a physical barrier after stimulation with bacterial components or inflammatory mediators, including IL-1 $\beta$ [20-22]. Thus, many studies have been focusing on identifying molecules, synthetic chemicals, or natural compounds that can suppress the production of inflammatory cytokines to control periodontal inflammation [23-25].

Recently, concerns have been raised about the use of synthetic drugs owing to their adverse effects and toxicity [26]. For example, $8 \%$ of hospital admissions in the US were reported to be caused by the adverse effects of synthetic drugs [27]. Thus, natural products, which are relatively safe and inexpensive, have been proposed as alternatives, and are considered to be free from undesirable adverse effects [28-30]. Moreover, deaths or hospitalizations in the US due to herbs are extremely rare [26]. Although the potential adverse effects and cellular toxicity of plant-derived natural products need to be elucidated, they are generally considered to be safe and effective. Korean traditional medicine has long relied on the use of natural products for the therapy or prevention of diseases [31,32].

Litsea japonica is an evergreen broadleaf species belonging to the family, Lauraceae. It is found in Jeollanamdo, Gyeongsangnamdo Island, Jeju, and Ulleungdo in Korea and in South Asian regions, including Japan. Numerous studies have shown that the extracts of L. japonica fruits have anti-inflammatory [33] and anti-diabetic effects [34], can protect against diabetic retinopathy [35], and can prevent osteoarthritis [36]. Although several biological activities of L. japonica extract have been reported, the effect of its leaf extract on periodontal disease has not yet been investigated. This study aimed to investigate the effect of L. japonica leaf extract (LJLE) on inflammation induced by various inflammatory stimuli, including LPS, several strains of oral bacteria, and IL- $1 \beta$, in the PDL.

\section{Results}

\subsection{Effect of LJLE on LPS-Induced Pro-Inflammatory Cytokine Expression in PDLFS}

To investigate whether LJLE affects LPS-induced pro-inflammatory cytokine production in periodontal ligament fibroblasts (PDLFs), we determined its effects on IL-6 and IL-8 mRNA expression in LPS-stimulated PDLFs. First, we determined the concentration- and time-dependent response of 
pro-inflammatory cytokines (IL-6 and IL-8) in PDLFs exposed to either Escherichia coli or P. gingivalis LPS (Supplementary Figures S1 and S2). Because the effect of E. coli LPS is known to differ from that of P. gingivalis LPS [37], we investigated cytokine production in PDLFs following stimulation by each LPS at various concentrations $(1,5$, and $10 \mu \mathrm{g} / \mathrm{mL})$ and different times. Furthermore, we found that 1 and $10 \mu \mathrm{g} / \mathrm{mL}$, respectively, of crude E. coli and P. gingivalis LPS could effectively induce inflammatory cytokine expression in PDLFs. Notably, cytokines were produced by only crude P. gingivalis LPS stimulation (Toll-like receptor 2 (TLR2) and TLR4 agonists), but not by ultrapure $P$. gingivalis LPS (TLR4 agonist). This result is in accordance with the findings reported by Hirschfeld et al. [38]. We found that $100 \mu \mathrm{g} / \mathrm{mL}$ of LJLE significantly reduced the IL-6 and IL-8 expression induced by E. coli $(1 \mu \mathrm{g} / \mathrm{mL})$ or $P$. gingivalis LPS $(10 \mu \mathrm{g} / \mathrm{mL})$ at all subsequent time points (Figure 1$)$. In addition, no cytotoxicity was observed following LJLE treatment of LPS-stimulated PDLFs (Supplementary Figure S3).

A

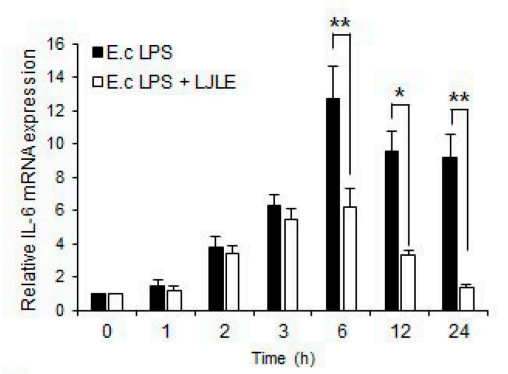

$\mathrm{C}$

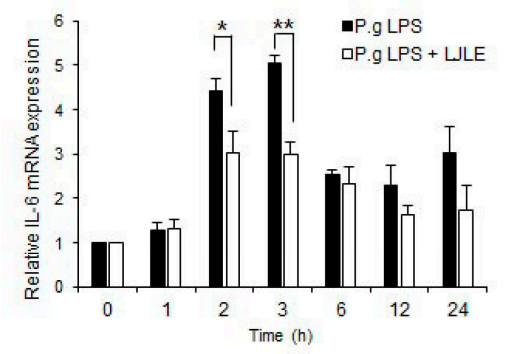

B

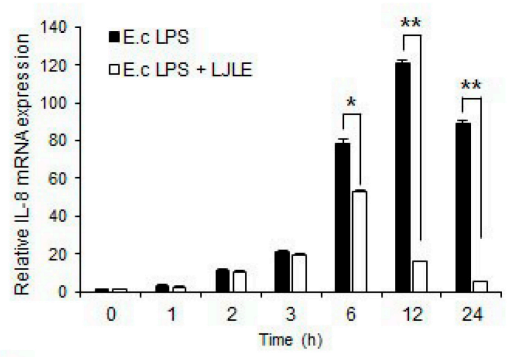

D

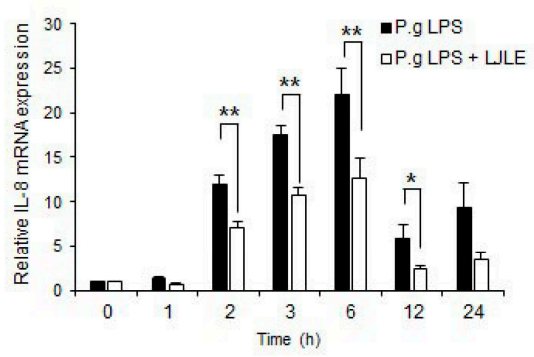

Figure 1. Litsea japonica leaf extract (LJLE) inhibits pro-inflammatory cytokine expression in lipopolysaccharide (LPS)-stimulated human periodontal ligament fibroblasts (PDLFs). Human PDLFs were stimulated with LPS in the absence or presence of $100 \mu \mathrm{g} / \mathrm{mL}$ LJLE for different times $(0,1,2,3,6$, 12 , and $24 \mathrm{~h}$ ). Real-time polymerase chain reaction (PCR) was performed as described in the Materials and Methods. (A,B) Time-course effects of LJLE on IL-6 and IL-8 mRNA in $1 \mathrm{ng} / \mathrm{mL}$ Escherichia coli (E.c) LPS-stimulated PDLFs. (C,D) Time-course effects of LJLE on IL-6 and IL-8 mRNA in $10 \mathrm{ng} / \mathrm{mL}$ Porphyromonas gingivalis (P.g) LPS-stimulated PDLFs. ${ }^{*} p<0.05$ and ${ }^{* *} p<0.01$ compared with LPS alone (unpaired two-tailed Student's $t$-test).

\subsection{Inhibitory Effect of LJLE on Pro-Inflammatory Cytokine Expression in Mixed Red Complex Bacteria-Infected PDLFs}

Next, to determine whether LJLE also suppresses pro-inflammatory cytokine expression by PDLFs after oral bacterial infection, we examined IL-6 and IL-8 expression levels in PDLFs treated with $100 \mu \mathrm{g} / \mathrm{mL}$ LJLE for varying times following infection with well-known periodontal pathogens (P. gingivalis, T. denticola, T. forsythia, and F. nucleatum). For bacterial infection, we attempted to use a combination of different strains. First, infection of PDLFs with a single bacterial strain revealed a relatively low cytokine production by the red complex strains (P. gingivalis, T. denticola, or T. forsythia) than that produced by F. nucleatum, and this effect was significantly decreased by LJLE treatment (Figure 2). Next, co-infection with each strain of the red complex bacteria with F. nucleatum led to a 10- to 100-fold increase in cytokine production, which was significantly decreased by LJLE treatment 
(Figure 3). Moreover, co-infection with all three strains of the red complex bacteria with F. nucleatum showed a remarkable increase in cytokine production (Figure 4), and treatment with LJLE significantly suppressed the IL-6 and IL-8 expression over the entire infection time course.

A
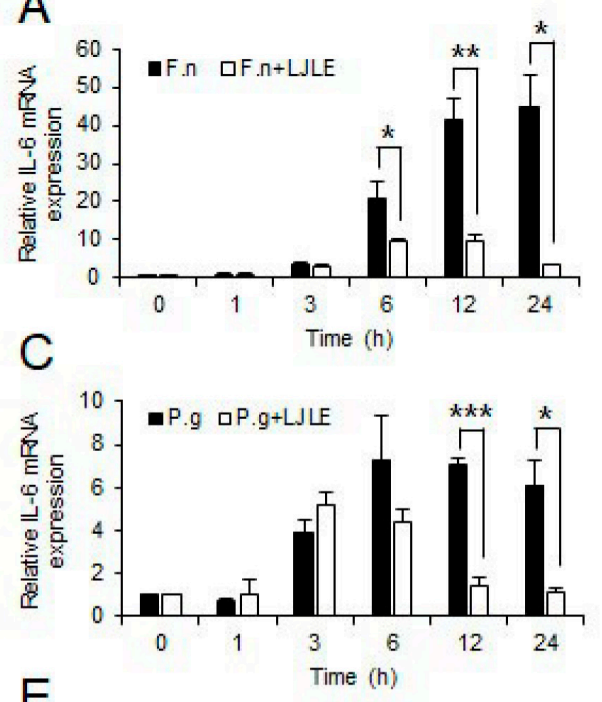

$E$
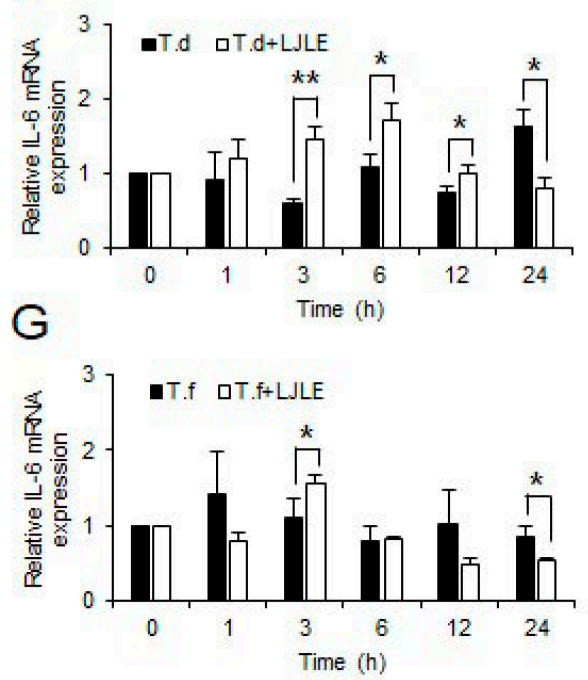

B
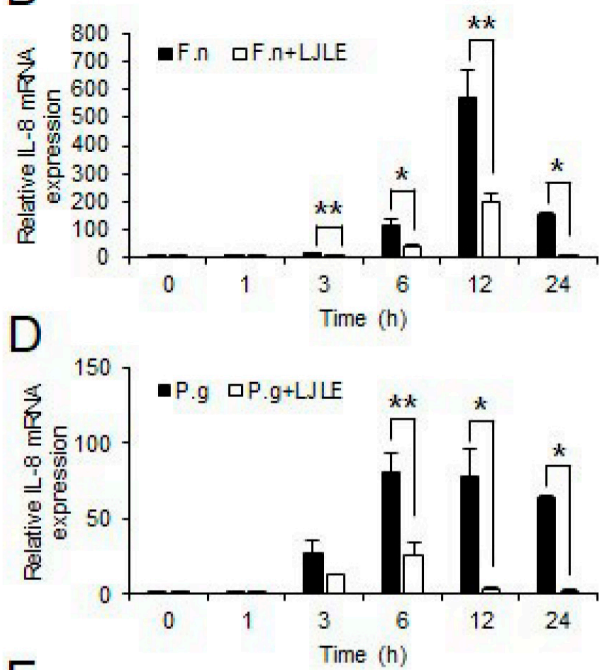

$\mathrm{F}$
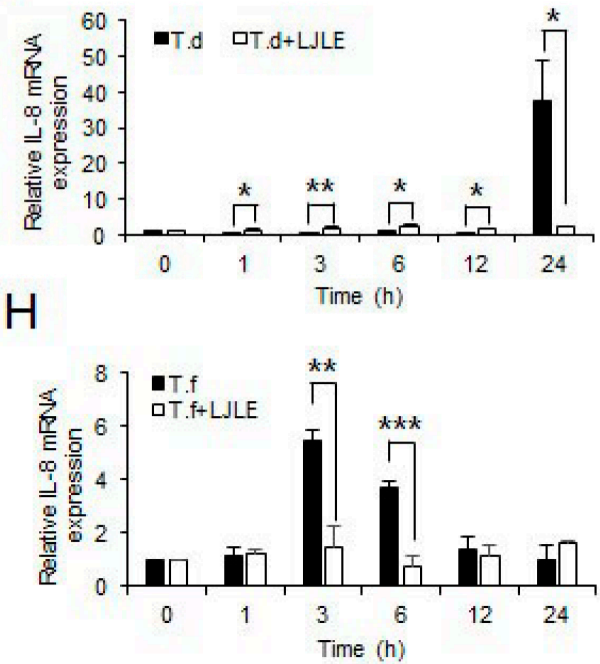

Figure 2. Inhibitory effect of LJLE on proinflammatory cytokine expression in human PDLFs infected with single species of oral bacteria at different time points $(0,1,2,3,6,12$, and $24 \mathrm{~h})$. IL-6 and IL-8 mRNA expression in human PDLFs infected with (A,B) F. nucleatum (F.n), (C,D) P. gingivalis (P.g), (E,F) T. denticola (T.d), and (G,H) T. forsythia (T.f) in the absence or presence of $100 \mu \mathrm{g} / \mathrm{mL}$ LJLE. Values are means \pm standard deviation (SD) of triplicate assays. ${ }^{*} p<0.05,{ }^{* *} p<0.01$, and ${ }^{* * *} p<0.001$ (unpaired two-tailed Student's $t$-test).

Because many studies have suggested that natural plant extracts show anti-inflammatory activity mediated by antioxidant or antimicrobial activity [39-41], we determined reactive oxygen species (ROS) generation and bacterial survival in F. nucleatum-infected PDLFs treated with LJLE. We found that $\mathrm{ROS}\left(\mathrm{H}_{2} \mathrm{O}_{2}\right)$ generation in F. nucleatum-infected PDLFs was not decreased by treatment with LJLE (Supplementary Figure S4), which also did not exhibit any bactericidal activity. 
A

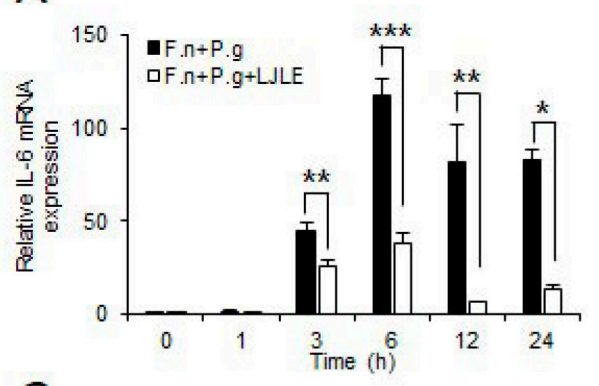

C

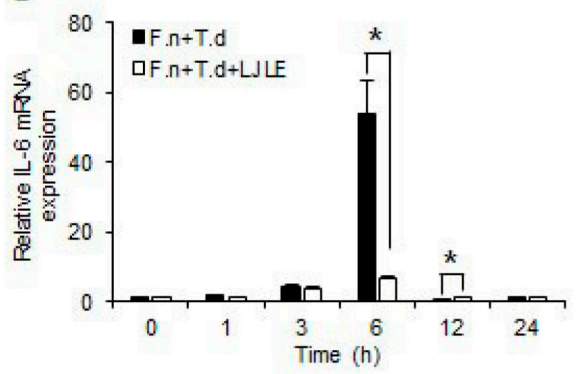

E

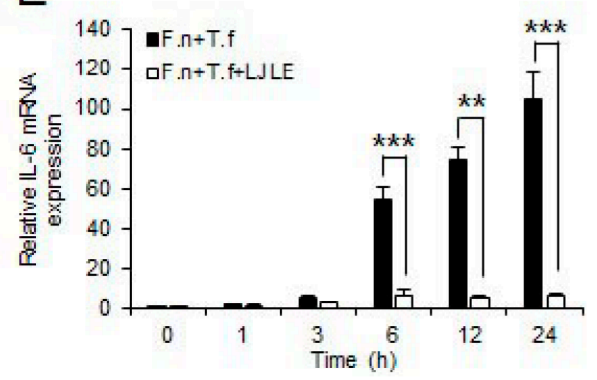

B

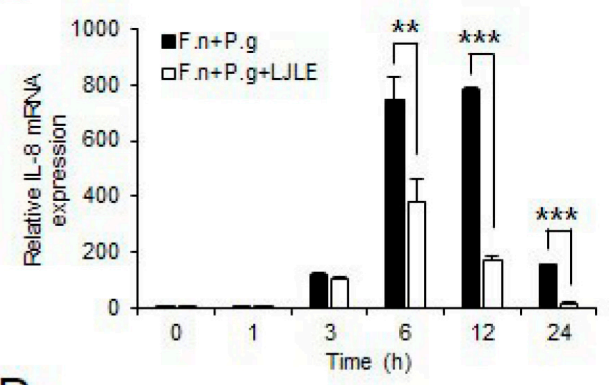

D

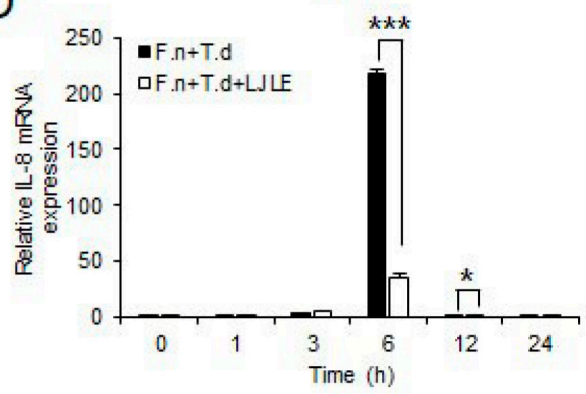

F

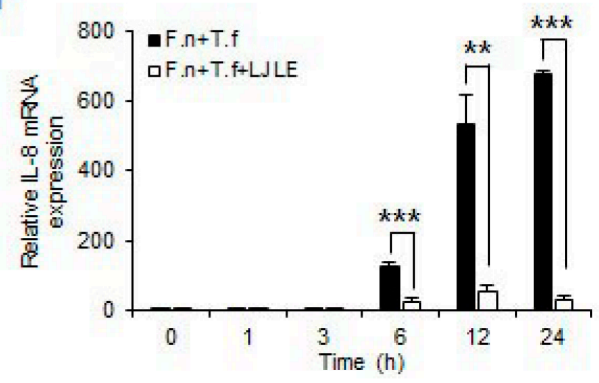

Figure 3. Inhibitory effect of LJLE on proinflammatory cytokine expression in human PDLFs infected with dual species of oral bacteria at different time points $(0,1,2,3,6,12$, and $24 \mathrm{~h})$. IL-6 and IL-8 mRNA expression in PDLFs infected with (A,B) F. nucleatum (F.n) plus P. gingivalis (P.g), (C,D) F. nucleatum plus T. denticola (T.d), and (E,F) F. nucleatum plus T. forsythia (T.f) in the absence or presence of $100 \mu \mathrm{g} / \mathrm{mL}$ LJLE. Values represent means \pm standard deviation (SD) of triplicate assays. ${ }^{*} p<0.05,{ }^{* *} p<0.01$, and *** $p<0.001$ (unpaired two-tailed Student's $t$-test).

2.3. Dose-Dependent Inhibitory Effects of Pre- and Post-Treatment with LJLE on Pro-Inflammatory Cytokine Production in LPS- or F. nucleatum-Infected PDLFs

To determine whether LJLE suppresses inflammation in LPS- or F. nucleatum-infected PDLFs in a concentration-dependent manner, we evaluated the mRNA expression level of pro-inflammatory cytokines (IL-6 and IL-8) in LPS- or F. nucleatum-infected PDLFs following treatment with LJLE at different concentrations $(0,10,50$, and $100 \mu \mathrm{g} / \mathrm{mL})$. Moreover, to ascertain whether the effect of LJLE was preventive or therapeutic, we treated PDLFs with LJLE at the indicated concentrations $2 \mathrm{~h}$ before or after infection with LPS or F. nucleatum. The incubation time for the treatment was determined based on the findings of previous studies on the effect of L. japonica fruit extract [42,43].

First, pretreatment with LJLE significantly reduced the mRNA expression levels of IL-6 and IL-8 in a concentration-dependent manner (Figure 5). For example, the mRNA expression levels of IL-6 and IL-8 in LPS- and F. nucleatum-infected PDLFs were downregulated by approximately 5- and 3-fold, respectively, after treatment with $10 \mu \mathrm{g} / \mathrm{mL}$ LJLE. Moreover, the expression of these cytokines was completely blocked by pretreatment with $100 \mu \mathrm{g} / \mathrm{mL}$ LJLE. 
A

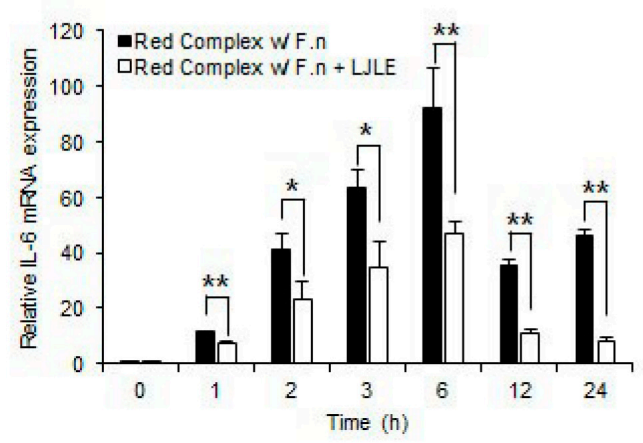

B

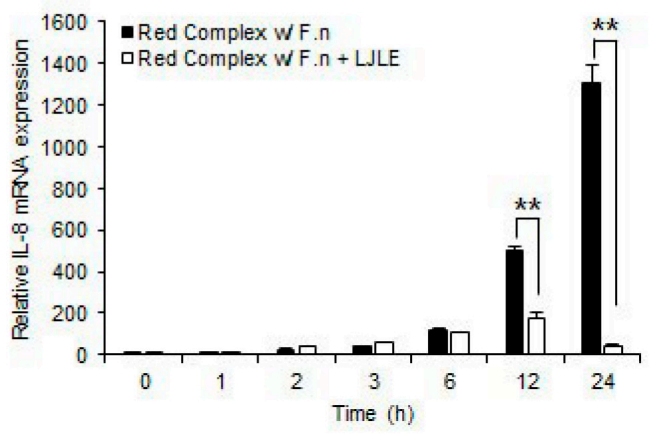

Figure 4. LJLE inhibits pro-inflammatory cytokine expression in mixed red complex bacteria, including F. nucleatum (F.n)-infected human PDLFs. Human PDLFs were stimulated with LPS in the absence or presence of $100 \mu \mathrm{g} / \mathrm{mL}$ LJLE for different times $(0,1,2,3,6,12$, and $24 \mathrm{~h})$. Real-time PCR was performed as described in the Materials and Methods. (A) Time-course of effects of LJLE on IL-6 and (B) IL-8 mRNA expression in mixed red complex (P. gingivalis, T. denticola, and T. forsythia), including F. nucleatum (F.n)-infected PDLFs. ${ }^{*} p<0.05$ and ${ }^{* *} p<0.01$ compared with bacterial infection alone (unpaired two-tailed Student's t-test).

A

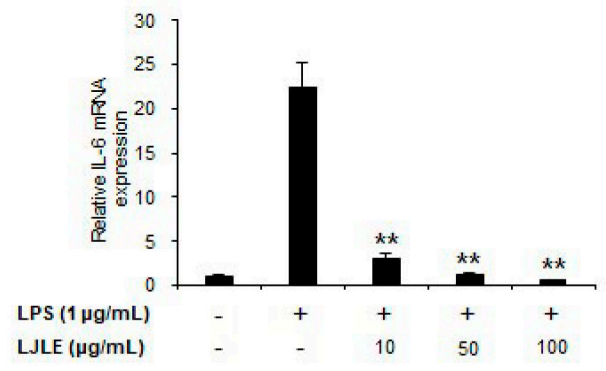

C

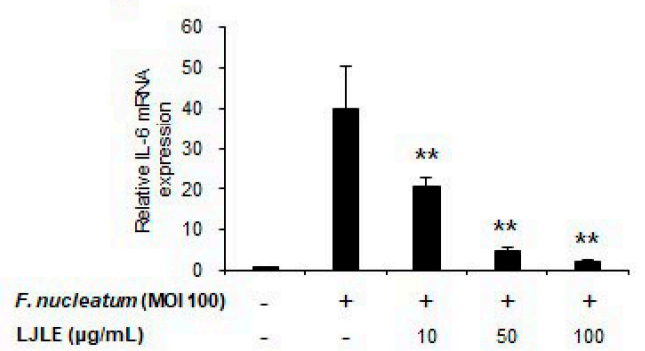

B

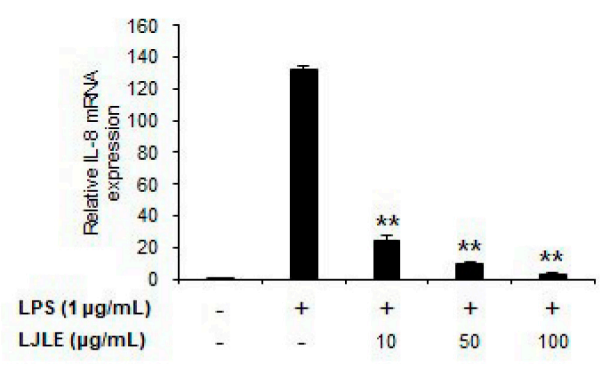

D

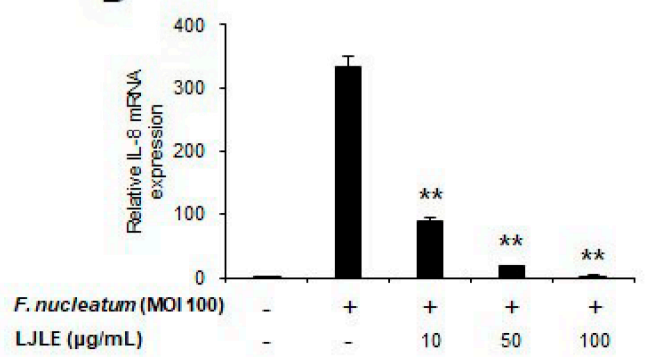

Figure 5. Pretreatment with LJLE inhibits pro-inflammatory cytokine expression in LPS or F. nucleatum-infected human PDLFs in a concentration-dependent manner. Human PDLFs were pretreated for $2 \mathrm{~h}$ with $0,10,50$, or $100 \mu \mathrm{g} / \mathrm{mL}$ LJLE, followed by stimulation with E. coli LPS or F. nucleatum (MOI 100) for $24 \mathrm{~h}$. Concentration-dependent inhibitory effect of LJLE pretreatment on IL-6 and IL-8 mRNA on (A,B) E. coli LPS-stimulated and (C,D) F. nucleatum-infected PDLFs. ${ }^{* *} p<0.01$ compared with LPS or F. nucleatum alone (unpaired two-tailed Student's $t$-tests).

Second, posttreatment with LJLE significantly reduced the mRNA expression levels of IL-6 and IL-8 in a concentration-dependent manner, but it was not as effective as pretreatment with LJLE. The mRNA expression levels of IL-6 and IL-8 in LPS-infected PDLFs were completely suppressed by $100 \mu \mathrm{g} / \mathrm{mL}$ LJLE (Supplementary Figure S5A,B). At the same concentration of LJLE 
in F. nucleatum-infected PDLFs, the expression of IL-6 and IL-8 was still approximately $21 \%$ and $7 \%$, respectively, compared to the level of untreated cells (Supplementary Figure S5C,D).

Next, to evaluate the effect of LJLE on protein expression levels of the pro-inflammatory cytokines, IL-6 and IL-8, in LPS- or F. nucleatum-infected PDLFs, we performed enzyme-linked immunosorbent assay (ELISA) to detect human IL-6 and IL-8 in cell culture supernatants. This experiment was also conducted using two different treatment methods, pre- and post-treatment, as described above. First, in the pretreatment setting, IL-6 and IL-8 protein production levels were decreased in LPS- or F. nucleatum-infected PDLFs in an LJLE concentration-dependent manner (Figure 6). Second, in the posttreatment setting, the protein levels of these cytokines were also significantly reduced by LJLE treatment, but this reduction was not as great as that following pretreatment (Supplementary Figure S6). Nevertheless, our results showed that, under both pretreatment and posttreatment conditions, LJLE effectively suppressed inflammatory cytokine production in LPS- or F. nucleatum-treated PDLFs.

A
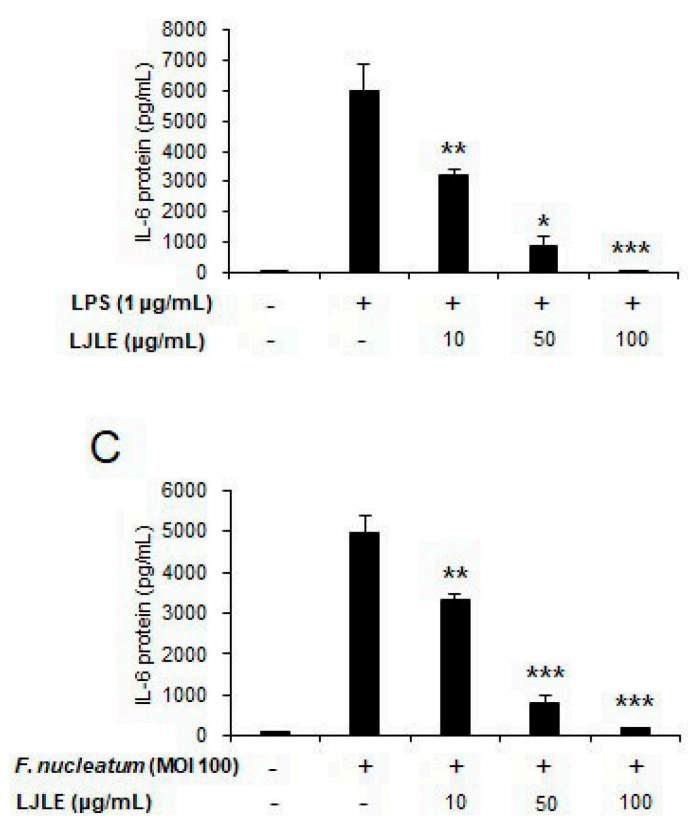

B
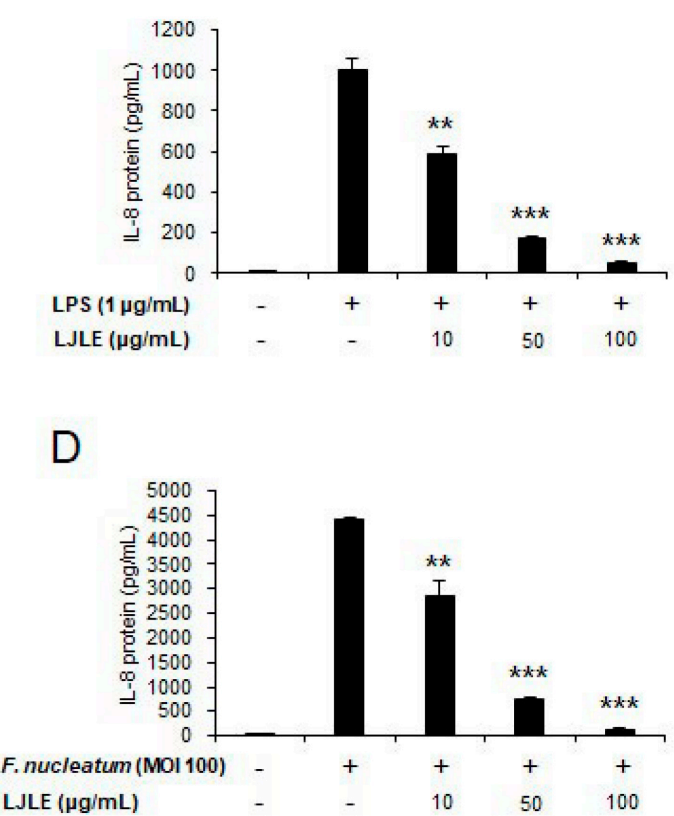

Figure 6. Pretreatment with LJLE inhibits pro-inflammatory cytokine secretion in LPS- or F. nucleatum-infected human PDLFs in a concentration-dependent manner. Human PDLFs were pretreated for $2 \mathrm{~h}$ with $0,10,50$, or $100 \mu \mathrm{g} / \mathrm{mL}$ LJLE, followed by stimulation with E. coli LPS or F. nucleatum (MOI 100) for $24 \mathrm{~h}$, and supernatants were analyzed using enzyme-linked immunosorbent assay (ELISA) to detect the presence of IL-6 and IL-8. Concentration-dependent inhibitory effect of LJLE pretreatment on IL-6 and IL-8 protein expression in (A,B) E. coli LPS-stimulated and (C,D) F. nucleatum-infected PDLFs. ${ }^{*} p<0.05,{ }^{* *} p<0.01$, and ${ }^{* * *} p<0.001$ compared with LPS or F. nucleatum alone (unpaired two-tailed Student's $t$-test).

\subsection{Inhibitory Effect of LJLE on IL-1 $\beta$-Induced Pro-Inflammatory Cytokine Production in PDLFs}

Inflammation is induced by stimulation with not only bacterial components (via TLR) but also IL-1 $\beta$ (via IL-1 $\beta$ signaling) in oral cells, and can exacerbate periodontal diseases [44]. Particularly, IL-1 $\beta$ is known to be a major mediator of periodontitis, and triggers the pro-inflammatory cytokines, IL-6 and IL-8, in gingival fibroblasts and PDLFs [21]. Thus, in this study, we assessed whether LJLE inhibits inflammation triggered by IL- $1 \beta$ stimulation in PDLFs. The expression of IL- 6 and IL- 8 mRNA was found to be significantly inhibited by LJLE in a concentration-dependent manner (Figure 7A,B). Accordingly, the protein expression levels of IL-6 and IL-8 were also significantly decreased by LJLE in a concentration-dependent manner (Figure 7C,D). 

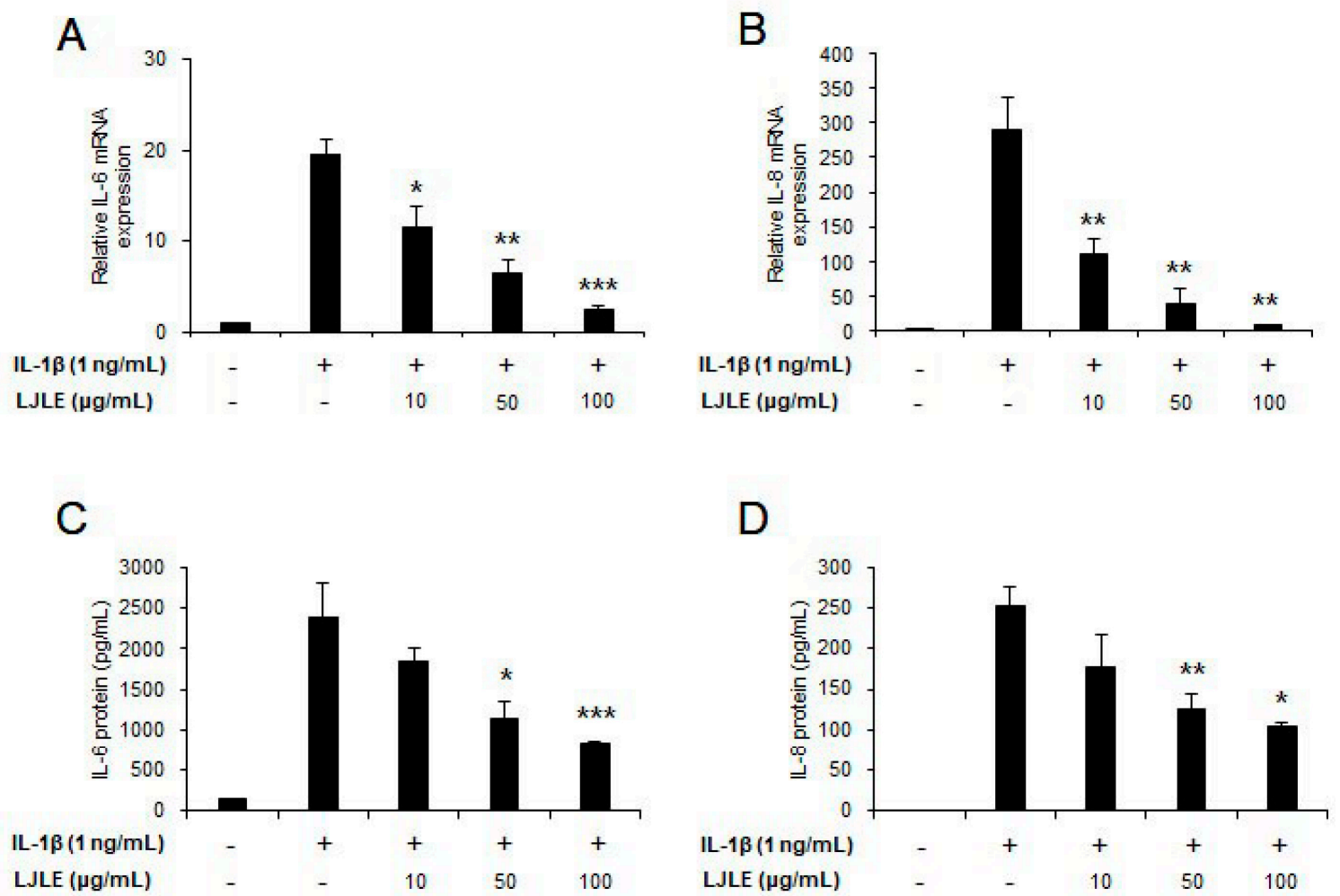

Figure 7. LJLE suppresses pro-inflammatory cytokine expression production in IL-1 $\beta$-stimulated human PDLFs. Human PDLFs were treated for $12 \mathrm{~h}$ with $0,10,50$, or $100 \mu \mathrm{g} / \mathrm{mL}$ LJLE in the absence or presence of $10 \mathrm{ng} / \mathrm{mL}$ IL-1 $\beta$. Concentration-dependent enhancing effects of LJLE on IL-6 and IL-8 (A,B) mRNA and (C,D) protein in IL-1 $\beta$-stimulated human PDLFs. ${ }^{*} p<0.05,{ }^{* *} p<0.01,{ }^{* * *} p<0.001$, and NS: Not significant compared with IL-1 $\beta$ alone (unpaired two-tailed Student's $t$-test).

\section{Discussion}

The most common risk factor for periodontal disease is oral bacteria, which grow on biofilms in an interdependent manner on the tooth surface $[45,46]$. Several toxic substances, such as endotoxins, mucinous peptides, fatty acids, organic acids, hydrogen sulfide, and leukotoxin, were detected in the biofilm produced by oral bacteria [47]. Periodontal tissues secrete pro-inflammatory cytokines in response to these stimulants, which leads to the recruitment and activation of immune cells. However, excessive inflammation results in tissue damage and bone destruction [48]. Therefore, suppressing inflammation can be an effective strategy for the development of preventive and therapeutic approaches to reduce periodontal disease severity.

Periodontal diseases are characterized by the loss of PDL and alveolar bone in the periodontal tissue caused by bacterial infection. Therefore, limiting inflammation of bacteria-infected PDL is important to reduce the risk of periodontal disease. Numerous bacterial species are known to be associated with periodontal disease. In this study, we first investigated the effect of LJLE on proinflammatory cytokines in PDL after stimulation with E. coli- or P. gingivalis-LPS (Figure 1). We found that LJLE might inhibit TLR2/4-mediated cytokine production in PDL. Thus, we next determined the suppressive effect of LJLE on proinflammatory cytokines in PDL after infection of several oral bacterial strains. Previously, we reported that $F$. nucleatum likely interacted with gingival fibroblasts in the connective tissue, and provided a favorable environment for other anaerobic bacteria, such as $P$. gingivalis $[14,15]$. F. nucleatum is an orange complex bacterium, and its prevalence is significantly associated with increasing pocket depth [49]. It is a less pathogenic bacterium compared with the red complex bacteria, but it is a strong inducer of chemokines and proinflammatory mediators in oral cells [50]. In this study, we also observed higher cytokine production in the PDL by F. nucleatum 
than by any other bacterial strain (Figure 2A,B). Among four bacterial strains, T. denticola and T. forsythia induced a relatively lower level of proinflammatory cytokines than other strains (F. nucleatum and P. gingivalis) in the PDL (Figure 2E-H). Notably, all four bacterial strains induced a remarkable production of IL-8 than IL-6. In particular, IL-6 induction levels in the PDL by T. denticola or T. forsythia were considerably low (about 1-1.5 fold) and did not show a suppressive effect of LJLE, whereas the remarkably elevated IL-8 in the PDL by T. denticola or T. forsythia was significantly suppressed by LJLE treatment (Figure 2E-H).

Moreover, numerous studies have shown that red complex bacteria (P. gingivalis, T. denticola, and T. forsythia) show increased virulence characteristics compared with orange complex bacteria, such as F. nucleatum, during interaction with host cells [51]. We also observed considerable enhancement of proinflammatory cytokine production in PDL upon coinfection with the red complex bacteria, with F. nucleatum and LJLE treatment significantly suppressing IL-6 and IL-8 expression (Figures 3 and 4).

Following stimulation with cytokines or bacteria, human primary oral cells secrete various inflammatory mediators, such as IL-6 and IL-8. IL-6 is an important mediator of the host response to injury and bacterial infection. It is known to be produced at considerably higher levels in patients with periodontitis than in healthy individuals. It is released from healthy human gingival fibroblasts following stimulation with oral pathogenic bacteria [14,15]. IL-8 is an important cytokine for maintaining a healthy periodontium because of its chemotactic activity that facilitates the infiltration of monocytes into periodontal tissues [49]. Moreover, IL-1 $\beta$ has been detected in the gingival fluid and tissues of patients with periodontal disease, but not in healthy individuals. It can also induce other inflammatory cytokines, such as IL-6 and IL-8, in gingival fibroblasts or PDL [52], which cause tissue destruction. Therefore, preventing excessive inflammation in periodontal tissues caused by various stimulants is important.

For the regulation of inflammation, antibiotics or non-steroidal anti-inflammatory drugs can be administered systemically. Non-steroidal anti-inflammatory drugs can cause various adverse effects in organs, including the gastrointestinal tract, nervous system, and liver [53]. The use of therapeutic systemic antibiotics has the potential to increase adverse effects and the incidence of several antibiotic-resistant strains [54]. Although oral bacteria are susceptible to various antibiotics, no single antibiotic that can inhibit all periodontal pathogens is available [55]. Oral cleansers can reduce gingivitis, but their efficacy in the prevention or treatment of periodontitis has not been established [56]. Moreover, local delivery of antimicrobial agents can enhance the suppression of subgingival pathogens [57]. Non-synthetic antibiotics, as well as phytochemicals, are used to treat periodontitis as adjuncts to nonsurgical treatment [58]. Therefore, exploring natural products, which are safer than conventional synthetic compounds, is recommended. Although the mechanisms by which natural products act are not well established, many studies have revealed their antioxidant activities [59] and other beneficial effects in the treatment of cancer [60-62], memory deficit, and Alzheimers [63]; atherosclerosis [64]; diabetes [65,66]; and other cardiovascular diseases [67]. Moreover, several plant-derived products have been suggested to have pharmacological effects in the prevention and treatment of periodontal diseases, such as the antibacterial effects of the extracts of maize [68], the anti-bone resorption activity of Magnoliae cortex extract [69], and the anti-inflammatory activity of elderberry [70].

In this study, we investigated the effect of LJLE on periodontal inflammation caused by bacterial infection or an inflammatory mediator. L. japonica has been used as a herbal medicine, and its fruit extract has been known to improve the symptoms of many diseases, including osteoarthritis [36], diabetes-induced retinal neurodegeneration [71], and blood-retinal barrier breakdown [72]. Recent studies about $L$. japonica have shown the effect of its fruit extract on inflammation in LPS-stimulated RAW264.7 cells [33,73-76]. One study suggested that the anti-inflammatory activity of L. japonica extract was due to its antioxidant activity, mediated by the inhibition of inducible nitric oxide synthase (iNOS) [74]. This study also showed the anti-inflammatory effect of LJLE on primary human oral cells triggered by various immunostimulants, including LPS, bacteria, and IL-1 $\beta$. However, we did 
not observe any inhibitory effect of LJLE on iNOS expression and, in fact, there was no induction of iNOS expression in PDL after stimulation with bacteria or IL-1 $\beta$. Moreover, we did not observe any reduction in ROS by LJLE treatment of PDLFs during bacterial infection. Thus, we believe that the anti-inflammatory effect of LJLE on PDLFs is not owing to its antioxidant activity and is not limited to only the TLR2/4-mediated inflammation, but also involves IL-1 $\beta$-signaling-mediated inflammation. Finally, the anti-inflammatory effect of LJLE is both preventive and therapeutic in primary oral cells without cellular cytotoxicity. Taken together, these results indicate that LJLE might be a promising natural substance for improving periodontal health. Further studies are needed to confirm the in vivo efficacy of LJLE by using animal models of periodontal disease.

\section{Materials and Methods}

\subsection{Ethics Statement}

The isolation of human PDLFs was approved by the Chonnam National University Dental Hospital Institutional Review Board (Approval No., CNUDH-2016-013; 20 October 2016). Written informed consent was obtained from all subjects after the nature and possible consequences of the studies were explained to them. All participants were adults who did not have periodontal disease.

\subsection{Preparation of $L J L E$}

The leaves and stems of L. japonica used in this experiment were collected from Jeju Island in Korea by the Jeju Biodiversity Research Institute, Jeju Technopark. The dried L. japonica leaves (100 g) were extracted with $80 \%$ ethanol three times for $24 \mathrm{~h}$ each at room temperature [76]. The lyophilized extract was sonicated six times for $8 \mathrm{~s}$ in $1 \mathrm{~mL}$ of $80 \%$ ethanol, mixed thoroughly, and stored in a refrigerator at $-20{ }^{\circ} \mathrm{C}$ until use.

\subsection{Bacterial Strains and Culture Condition}

The F. nucleatum subspecies polymorphum American Type Culture Collection (ATCC) $10953^{\mathrm{T}}$, P. gingivalis KCOM 2804, T. denticola ATCC $35405^{\mathrm{T}}$, and T. forsythia ATCC $43037^{\mathrm{T}}$ were provided by the Korean Collection for Oral Microbiology (Gwangju, Korea) and purchased from ATCC (Manassas, VA, USA). Briefly, bacterial cultures were prepared by culturing P. gingivalis and F. nucleatum in medium containing $0.5 \%$ yeast extract, $0.05 \%$ cysteine $\mathrm{HCl}-\mathrm{H}_{2} \mathrm{O}, 10 \mu \mathrm{g} / \mathrm{mL}$ hemin, and $2 \mu \mathrm{g} / \mathrm{mL}$ vitamin $\mathrm{K} 1 \mathrm{in}$ Tryptic Soy Broth. T. forsythia was cultured by adding $10 \mu \mathrm{g} / \mathrm{mL} \mathrm{N}$-acetylmuraminic acid (Sigma, St. Louis, MO, USA) to the above medium. T. denticola was added to the heart infusion broth with $1.0 \%$ trypticase peptone, $0.25 \%$ yeast extract, $0.05 \%$ sodium thioglycollate, $0.1 \%$ L-cysteine $\mathrm{HCl}-\mathrm{H}_{2} \mathrm{O}, 0.025 \%$ L-asparagine, $0.2 \%$ D-glucose, $0.0001 \%$ resazurin, $0.20025 \%$ sodium bicarbonate, $2 \%$ rabbit serum, and $2 \%$ thiamine pyrophosphate (TPP)/volatile fatty acid solution $(0.03 \% \mathrm{TPP}, 0.05 \%$ isobutyric acid, $0.05 \%$ 2-methylbutyric acid, $0.05 \%$ isovaleric acid, $0.05 \%$ valeric acid, and $0.098 \mathrm{~N}$ sodium hydroxide). These strains were cultured under anaerobic conditions $\left(10 \% \mathrm{H}_{2}, 5 \% \mathrm{CO}_{2}\right.$, and $\left.85 \% \mathrm{~N}_{2}\right)$ in a $37^{\circ} \mathrm{C}$ anaerobic chamber (Bactron I; Sheldon Manufacturing Inc., Cornelius, OR, USA) [14]. The culture broth absorbance was measured at $600 \mathrm{~nm}$, and the number of bacteria was counted. The bacteria were collected by centrifugation $(7000 \times g, 10 \mathrm{~min})$, and washed in phosphate-buffered saline before the cell suspension density was adjusted to $2 \times 10^{7}$ colony forming unit (CFU) $/ 5 \mu \mathrm{L}$ in the buffer as the multiplicity of infection (MOI) of 200. Cells were incubated for the appropriate time and then washed twice with PBS.

\subsection{Culture of Primary PDLFs}

Primary human PDLFs were prepared as described by Somerman et al. [77]. Collection of human PDL from the premolar and third molar was approved by the Institutional Review Board of Chonnam National University Dental Hospital (Approval No., CNUDH-2016-013; 20 October 2016). All participants were adults without periodontal disease. The PDLFs were grown in Dulbecco's 
modified Eagle's medium (Gibco BRL, Waltham, MA, USA) supplemented with $10 \%$ heat-inactivated fetal bovine serum (GenDepot, Katy, TX, USA), $100 \mathrm{U} / \mathrm{mL}$ penicillin, and $100 \mu \mathrm{g} / \mathrm{mL}$ streptomycin (GenDepot, USA) at $37{ }^{\circ} \mathrm{C}$ in a humidified atmosphere containing $5 \% \mathrm{CO}_{2}$. When they achieved confluence, the cells were trypsinized using $0.25 \%$ trypsin $/ 0.02 \%$ ethylenediaminetetraacetic acid solution (Sigma-Aldrich, St. Louis, MO, USA). Cells in which PDLFs proliferated sufficiently were sub-cultured five to six times at a ratio of $1: 2$ to $1: 3$ in a $100 \mathrm{~mm}$ culture dish and were used in this experiment.

\subsection{Measurement of Cell Viability}

To evaluate the cytotoxicity of LJLE, we used the 3-(4,5-dimethylthiazol-2-yl)-2,5diphenyltetrazolium bromide (MTT) colorimetric assay to measure cell viability after treatment with inhibitors [78]. PDLFs were seeded into 96-well plates at a density of $10^{4}$ cells/well in DMEM containing $10 \%$ fetal bovine serum. The cells were incubated with an appropriate concentration of the extract with E. coli or P. gingivalis LPS at the indicated concentration and time, after which the medium was carefully replaced with fresh medium containing MTT (EZ-Cytox; DoGenBio, Gwangju, Korea) solution, and the incubation was continued for an additional $3 \mathrm{~h}$ at $37{ }^{\circ} \mathrm{C}$ in an atmosphere of $5 \%$ carbon dioxide. The same volume of $10 \%$ sodium dodecyl sulfate in $0.01 \mathrm{M}$ hydrochloric acid solution was added to each well, followed by thorough mixing using a pipette, and then the incubation was continued for another $3 \mathrm{~h}$. The absorbance at $450 \mathrm{~nm}$ was measured using a microplate reader (Bio-Rad Laboratories, Hercules, CA, USA). Reported values are the means of triplicates (one line of 96-well microplate) and are expressed as a percentage of control values (A450 of inhibitor/A450 of control) $\times 100$.

\subsection{Quantitative Real-Time PCR}

Total RNA was isolated using RNeasy kits (Qiagen, Hilden, Germany) primed with random hexamer oligonucleotides and was reverse transcribed using a PrimeScript RT Reagent kit (Takara Biotechnology, Tokyo, Japan). Real-time quantitative PCR was performed using SYBR Green Master Mix (Takara Biotechnology, Tokyo, Japan) and the following primers: Human IL-6 F: $5^{\prime}$-agggctcttcggcaaatgta- $3^{\prime}$ and R: $5^{\prime}$-tgcccagtggacaggtttc- $3^{\prime}$, and human IL-8 F: $5^{\prime}$-tttctgttaaatctggcaaccctagt- $3^{\prime}$ and R: $5^{\prime}$-ataaaggagaaaccaaggcacagt- $3^{\prime}$. All data were normalized to human glyceraldehyde 3-phosphate dehydrogenase (GAPDH).

\subsection{ELISA}

IL-6 and IL-8 concentrations in the secreted cell culture supernatants were quantified using commercially available human-specific ELISA kits (Biolegend, San Diego, CA, USA). Briefly, 96-well plates were coated with anti-human IL-6 or IL-8 monoclonal antibodies. After blocking with the assay solution for $2 \mathrm{~h}$ to avoid non-specific binding, $100 \mu \mathrm{L}$ of the standard IL-6, IL-8, or culture supernatants were added. The cytokines were detected using a horseradish peroxidase-labeled monoclonal antibody to each target protein after $100 \mu \mathrm{L}$ of the anti-human biotinylated antibodies were added to each well and incubated for $2 \mathrm{~h}$ at $21^{\circ} \mathrm{C}$. The microplate was washed to remove the unbound enzyme-labeled antibodies. The amount of horseradish peroxidase bound to each well was determined by adding the substrate solution. The reaction was stopped by the addition of sulfuric acid, and the plates were read at $450 \mathrm{~nm}$ by using a SpectaMax i3X micro-titer plate reader (San Jose, CA, USA). The concentrations of each target were determined by interpolation from a standard curve and presented as picograms per milliliters ( $\mathrm{pg} / \mathrm{mL} \pm$ one standard error of the mean).

\subsection{Statistical Analysis}

Statistical analysis was performed using one-way analysis of variance (ANOVA) with Tukey's test by using the Statistical Packages for Social Science (SPSS, 23.0, Chicago, IL, USA). Furthermore, $p$-values $<0.05$ were considered statistically significant and are indicated by asterisks in the figures. 
Values are the means \pm SD (indicated by error bars) of three independent experiments performed in triplicate.

\section{Conclusions}

In this study, we found that LJLE is effective for the suppression of mRNA and protein expression of proinflammatory cytokines (IL-6 and IL-8) induced by various inflammatory stimuli, including LPS, oral pathogens, and IL-1 $\beta$, in the PDL after both pre- and post-treatments. The results of this study suggest that LJLE could possibly be used for the prevention and treatment of inflammatory periodontal disease.

Supplementary Materials: Supplementary materials can be found at http://www.mdpi.com/1422-0067/19/9/ 2494/s1.

Author Contributions: C.-H.C. and T.-H.L. conceived and designed the experiments; I.-G.Y., S.H.A., Y.K.L., and J.-K.K. performed the experiments; I.-G.Y. and S.-H.A. analyzed the data; W.-J.Y., C.S.K., and S.J. provided reagents; I.-G.Y., S.-H.A., and T.-H.L. drafted the manuscript.

Funding: This research was supported by Basic Science Research Program through the National Research Foundation of Korea (NRF) funded by the Ministry of Science, ICT and Future Planning (NRF-2017R1A2B2005938). Sun-Hee Ahn received funding from the Basic Science Research Program (2016R1A6A3A11932468) through the NRF funded by the Ministry of Education.

Conflicts of Interest: The authors declare no conflict of interest.

$\begin{array}{ll}\text { Abbreviations } \\ \text { PDL } & \text { Periodontal ligament } \\ \text { PDLFs } & \text { Periodontal ligament fibroblasts } \\ \text { LJLE } & \text { Litsea japonica leave extract } \\ \text { LPS } & \text { Lipopolysaccharide } \\ \text { IL-6 } & \text { Interleukin-6 } \\ \text { IL-8 } & \text { Interleukin-8 } \\ \text { SD } & \text { Standard deviation } \\ \text { TLR } & \text { Toll-like receptor } \\ \text { mRNA } & \text { Messenger ribonucleic acid } \\ \text { IL-1 } \beta & \text { Interleukin-1 beta } \\ \text { ROS } & \text { Reactive oxygen species } \\ \text { iNOS } & \text { Inducible nitric oxide synthase } \\ \text { MOI } & \text { Multiplicity of infection } \\ \text { TPP } & \text { Thiamine pyrophosphate } \\ \text { CFU } & \text { Colony forming unit } \\ \text { MTT } & \text { 3-(4,5-Dimethylthiazol-2-yl)-2,5-diphenyltetrazolium bromide } \\ \text { PCR } & \text { Polymerase chain reaction } \\ \text { GAPDH } & \text { Glyceraldehyde 3-phosphate dehydrogenase } \\ \text { ELISA } & \text { Enzyme-linked immunosorbent assay } \\ \text { DCF } & \text { Dichlorofluorescein fluorescence }\end{array}$

\section{References}

1. Angelillo, I.F.; Nobile, C.G.; Pavia, M. Survey of reasons for extraction of permanent teeth in Italy. Community Dent. Oral Epidemiol. 1996, 24, 336-340. [CrossRef] [PubMed]

2. Ong, G. Periodontal reasons for tooth loss in an Asian population. J. Clin. Periodontol. 1996, 23, 307-309. [CrossRef] [PubMed]

3. Kinane, D.F.; Stathopoulou, P.G.; Papapanou, P.N. Periodontal diseases. Nat. Rev. Dis. Primers 2017, 3, 17038. [CrossRef] [PubMed]

4. Tang, X.; Pan, Y.; Zhao, Y. Vitamin D inhibits the expression of interleukin-8 in human periodontal ligament cells stimulated with Porphyromonas gingivalis. Arch. Oral Biol. 2013, 58, 397-407. [CrossRef] [PubMed] 
5. Han, S.J.; Jeong, S.Y.; Nam, Y.J.; Yang, K.H.; Lim, H.S.; Chung, J. Xylitol inhibits inflammatory cytokine expression induced by lipopolysaccharide from Porphyromonas gingivalis. Clin. Diagn. Lab. Immunol. 2005, 12, 1285-1291. [CrossRef] [PubMed]

6. Haffajee, A.D.; Cugini, M.A.; Tanner, A.; Pollack, R.P.; Smith, C.; Kent, R.L., Jr.; Socransky, S.S. Subgingival microbiota in healthy, well-maintained elder and periodontitis subjects. J. Clin. Periodontol. 1998, 25, 346-353. [CrossRef] [PubMed]

7. Haffajee, A.D.; Socransky, S.S. Microbial etiological agents of destructive periodontal diseases. Periodontology 2000 1994, 5, 78-111. [CrossRef] [PubMed]

8. Socransky, S.S.; Haffajee, A.D. Dental biofilms: Difficult therapeutic targets. Periodontology 2000 2002, 28, 12-55. [CrossRef] [PubMed]

9. Bodet, C.; Chandad, F.; Grenier, D. Pathogenic potential of Porphyromonas gingivalis, Treponema denticola and Tannerella forsythia, the red bacterial complex associated with periodontitis. Pathol. Biol. 2007, 55, 154-162. [CrossRef] [PubMed]

10. Steffen, M.J.; Holt, S.C.; Ebersole, J.L. Porphyromonas gingivalis induction of mediator and cytokine secretion by human gingival fibroblasts. Oral Microbiol. Immunol. 2000, 15, 172-180. [CrossRef] [PubMed]

11. Holt, S.C.; Ebersole, J.L. Porphyromonas gingivalis, Treponema denticola, and Tannerella forsythia: The "red complex", a prototype polybacterial pathogenic consortium in periodontitis. Periodontology 2000 2005, 38, 72-122. [CrossRef] [PubMed]

12. Kolenbrander, P.E. Oral microbial communities: Biofilms, interactions, and genetic systems. Annu. Rev. Microbiol. 2000, 54, 413-437. [CrossRef] [PubMed]

13. Van Winkelhoff, A.J.; Loos, B.G.; van der Reijden, W.A.; van der Velden, U. Porphyromonas gingivalis, Bacteroides forsythus and other putative periodontal pathogens in subjects with and without periodontal destruction. J. Clin. Periodontol. 2002, 29, 1023-1028. [CrossRef] [PubMed]

14. Ahn, S.H.; Song, J.E.; Kim, S.; Cho, S.H.; Lim, Y.K.; Kook, J.K.; Kook, M.S.; Lee, T.H. NOX1/2 activation in human gingival fibroblasts by Fusobacterium nucleatum facilitates attachment of Porphyromonas gingivalis. Arch. Microbiol. 2016, 198, 573-583. [CrossRef] [PubMed]

15. Ahn, S.H.; Cho, S.H.; Song, J.E.; Kim, S.; Oh, S.S.; Jung, S.; Cho, K.A.; Lee, T.H. Caveolin-1 serves as a negative effector in senescent human gingival fibroblasts during Fusobacterium nucleatum infection. Mol. Oral Microbiol. 2017, 32, 236-249. [CrossRef] [PubMed]

16. Morandini, A.C.; Sipert, C.R.; Ramos-Junior, E.S.; Brozoski, D.T.; Santos, C.F. Periodontal ligament and gingival fibroblasts participate in the production of TGF-beta, interleukin (IL)-8 and IL-10. Braz. Oral Res. 2011, 25, 157-162. [CrossRef] [PubMed]

17. Yamaji, Y.; Kubota, T.; Sasaguri, K.; Sato, S.; Suzuki, Y.; Kumada, H.; Umemoto, T. Inflammatory cytokine gene expression in human periodontal ligament fibroblasts stimulated with bacterial lipopolysaccharides. Infect. Immun. 1995, 63, 3576-3581. [PubMed]

18. Yamamoto, T.; Kita, M.; Oseko, F.; Nakamura, T.; Imanishi, J.; Kanamura, N. Cytokine production in human periodontal ligament cells stimulated with Porphyromonas gingivalis. J. Periodontal Res. 2006, 41, 554-559. [CrossRef] [PubMed]

19. Arango Duque, G.; Descoteaux, A. Macrophage cytokines: Involvement in immunity and infectious diseases. Front. Immunol. 2014, 5, 491. [CrossRef] [PubMed]

20. Andrukhov, O.; Ulm, C.; Reischl, H.; Nguyen, P.Q.; Matejka, M.; Rausch-Fan, X. Serum cytokine levels in periodontitis patients in relation to the bacterial load. J. Periodontol. 2011, 82, 885-892. [CrossRef] [PubMed]

21. Murakami, S.; Hashikawa, T.; Saho, T.; Takedachi, M.; Nozaki, T.; Shimabukuro, Y.; Okada, H. Adenosine regulates the IL-1 beta-induced cellular functions of human gingival fibroblasts. Int. Immunol. 2001, 13, 1533-1540. [CrossRef] [PubMed]

22. Guan, S.M.; Shu, L.; Fu, S.M.; Liu, B.; Xu, X.L.; Wu, J.Z. Prevotella intermedia induces matrix metalloproteinase-9 expression in human periodontal ligament cells. FEMS Microbiol. Lett. 2008, 283, 47-53. [CrossRef] [PubMed]

23. Salvi, G.E.; Lang, N.P. Host response modulation in the management of periodontal diseases. J. Clin. Periodontol. 2005, 32 (Suppl. 6), 108-129. [CrossRef]

24. Gasparrini, M.; Forbes-Hernandez, T.Y.; Giampieri, F.; Afrin, S.; Mezzetti, B.; Quiles, J.L.; Bompadre, S.; Battino, M. Protective Effect of Strawberry Extract against Inflammatory Stress Induced in Human Dermal Fibroblasts. Molecules 2017, 22, 164. [CrossRef] [PubMed] 
25. Zuzarte, M.; Alves-Silva, J.M.; Alves, M.; Cavaleiro, C.; Salgueiro, L.; Cruz, M.T. New insights on the anti-inflammatory potential and safety profile of Thymus carnosus and Thymus camphoratus essential oils and their main compounds. J. Ethnopharmacol. 2018, 225, 10-17. [CrossRef] [PubMed]

26. Karimi, A.; Majlesi, M.; Rafieian-Kopaei, M. Herbal versus synthetic drugs; beliefs and facts. J. Nephropharmacol. 2015, 4, 27-30. [PubMed]

27. Gao, S.M.; Liu, J.S.; Wang, M.; Cao, T.T.; Qi, Y.D.; Zhang, B.G.; Sun, X.B.; Liu, H.T.; Xiao, P.G. Traditional uses, phytochemistry, pharmacology and toxicology of Codonopsis: A review. J. Ethnopharmacol. 2018, 219, 50-70. [CrossRef] [PubMed]

28. Nasri, H. Cisplatin therapy and the problem of gender-related nephrotoxicity. J. Nephropharmacol. 2013, 2, 13-14. [PubMed]

29. Huntley, A. The safety of black cohosh (Actaea racemosa, Cimicifuga racemosa). Expert Opin. Drug Saf. 2004, 3, 615-623. [CrossRef] [PubMed]

30. Hasani-Ranjbar, S.; Nayebi, N.; Larijani, B.; Abdollahi, M. A systematic review of the efficacy and safety of herbal medicines used in the treatment of obesity. World J. Gastroenterol. 2009, 15, 3073-3085. [CrossRef] [PubMed]

31. Yoon, S.W.; Jeong, J.S.; Kim, J.H.; Aggarwal, B.B. Cancer Prevention and Therapy: Integrating Traditional Korean Medicine Into Modern Cancer Care. Integr. Cancer Ther. 2014, 13, 310-331. [CrossRef] [PubMed]

32. Kang, Y.M.; Komakech, R.; Karigar, C.S.; Saqib, A. Traditional Indian medicine (TIM) and traditional Korean medicine (TKM): Aconstitutional-based concept and comparison. Integr. Med. Res. 2017, 6, $105-113$. [CrossRef] [PubMed]

33. Koo, H.J.; Yoon, W.J.; Sohn, E.H.; Ham, Y.M.; Jang, S.A.; Kwon, J.E.; Jeong, Y.J.; Kwak, J.H.; Sohn, E.; Park, S.Y.; et al. The analgesic and anti-inflammatory effects of Litsea japonica fruit are mediated via suppression of NF-kappaB and JNK/p38 MAPK activation. Int. Immunopharmacol. 2014, 22, 84-97. [CrossRef] [PubMed]

34. Sohn, E.; Kim, J.; Kim, C.S.; Lee, Y.M.; Jo, K.; Shin, S.D.; Kim, J.H.; Kim, J.S. The Extract of Litsea japonica Reduced the Development of Diabetic Nephropathy via the Inhibition of Advanced Glycation End Products Accumulation in db/db Mice. Evid. Based Complement. Altern. Med. 2013, 2013, 769416. [CrossRef] [PubMed]

35. Zhang, J.; Liu, R.; Kuang, H.Y.; Gao, X.Y.; Liu, H.L. Protective treatments and their target retinal ganglion cells in diabetic retinopathy. Brain Res. Bull. 2017, 132, 53-60. [CrossRef] [PubMed]

36. Jeong, Y.J.; Kim, I.; Cho, J.H.; Park, D.W.; Kwon, J.E.; Jung, M.W.; Meng, X.; Jo, S.M.; Song, H.S.; Cho, Y.M.; et al. Anti-Osteoarthritic Effects of the Litsea japonica Fruit in a Rat Model of Osteoarthritis Induced by Monosodium Iodoacetate. PLoS ONE 2015, 10, e0134856. [CrossRef] [PubMed]

37. Andrukhov, O.; Ertlschweiger, S.; Moritz, A.; Bantleon, H.P.; Rausch-Fan, X. Different effects of P. gingivalis LPS and E. coli LPS on the expression of interleukin-6 in human gingival fibroblasts. Acta Odontol. Scand. 2014, 72, 337-345. [CrossRef] [PubMed]

38. Hirschfeld, M.; Weis, J.J.; Toshchakov, V.; Salkowski, C.A.; Cody, M.J.; Ward, D.C.; Qureshi, N.; Michalek, S.M.; Vogel, S.N. Signaling by toll-like receptor 2 and 4 agonists results in differential gene expression in murine macrophages. Infect. Immun. 2001, 69, 1477-1482. [CrossRef] [PubMed]

39. Coyle, C.H.; Philips, B.J.; Morrisroe, S.N.; Chancellor, M.B.; Yoshimura, N. Antioxidant effects of green tea and its polyphenols on bladder cells. Life Sci. 2008, 83, 12-18. [CrossRef] [PubMed]

40. Choi, E.M.; Kim, G.H.; Lee, Y.S. Carthamus tinctorius flower extract prevents $\mathrm{H}_{2} \mathrm{O}_{2}$-induced dysfunction and oxidative damage in osteoblastic MC3T3-E1 cells. Phytother. Res. 2010, 24, 1037-1041. [PubMed]

41. Elisha, I.L.; Botha, F.S.; McGaw, L.J.; Eloff, J.N. The antibacterial activity of extracts of nine plant species with good activity against Escherichia coli against five other bacteria and cytotoxicity of extracts. BMC Complement. Altern. Med. 2017, 17, 133. [CrossRef] [PubMed]

42. Won, J.; Kim, J.E.; Choi, D.H.; Han, M.W.; Lee, D.H.; Kang, S.C.; Song, Y.J. Effects of compounds isolated from a Litsea japonica fruit extract on the TNF- $\alpha$ signaling pathway and cell viability. Mol. Cell. Toxicol. 2016, 12, 37-44. [CrossRef]

43. Kim, S.H.; Choi, H.J.; Yang, W.K.; Lee, J.E.; Cho, J.H.; Park, I.J.; Park, S.; Park, B.K.; Jin, M. Suppressive Effect of the n-Hexane Extract of Litsea japonica Fruit Flesh on Monosodium-Iodoacetate-Induced Osteoarthritis in Rats. Evid. Based Complement. Altern. Med. 2017, 2017, 1791403. [CrossRef] [PubMed]

44. Noh, M.K.; Jung, M.; Kim, S.H.; Lee, S.R.; Park, K.H.; Kim, D.H.; Kim, H.H.; Park, Y.G. Assessment of IL-6, IL-8 and TNF-alpha levels in the gingival tissue of patients with periodontitis. Exp. Ther. Med. 2013, 6, 847-851. [CrossRef] [PubMed] 
45. Tanner, A.; Maiden, M.F.; Macuch, P.J.; Murray, L.L.; Kent, R.L., Jr. Microbiota of health, gingivitis, and initial periodontitis. J. Clin. Periodontol. 1998, 25, 85-98. [CrossRef] [PubMed]

46. Ximenez-Fyvie, L.A.; Haffajee, A.D.; Socransky, S.S. Comparison of the microbiota of supra- and subgingival plaque in health and periodontitis. J. Clin. Periodontol. 2000, 27, 648-657. [CrossRef]

47. Socransky, S.S.; Haffajee, A.D. Evidence of bacterial etiology: A historical perspective. Periodontology 2000 1994, 5, 7-25. [CrossRef] [PubMed]

48. Delima, A.J.; Karatzas, S.; Amar, S.; Graves, D.T. Inflammation and tissue loss caused by periodontal pathogens is reduced by interleukin-1 antagonists. J. Infect. Dis. 2002, 186, 511-516. [CrossRef] [PubMed]

49. Darveau, R.P.; Belton, C.M.; Reife, R.A.; Lamont, R.J. Local chemokine paralysis, a novel pathogenic mechanism for Porphyromonas gingivalis. Infect. Immun. 1998, 66, 1660-1665. [PubMed]

50. Jang, J.Y.; Song, I.S.; Baek, K.J.; Choi, Y.; Ji, S. Immunologic characteristics of human gingival fibroblasts in response to oral bacteria. J. Periodontal Res. 2017, 52, 447-457. [CrossRef] [PubMed]

51. Ji, S.; Choi, Y.S.; Choi, Y. Bacterial invasion and persistence: Critical events in the pathogenesis of periodontitis? J. Periodontal Res. 2015, 50, 570-585. [CrossRef] [PubMed]

52. Ahn, S.H.; Lee, J.K.; Kim, N.D.; Kim, S.H.; Lee, S.; Jung, S.; Chay, K.O.; Lee, T.H. DPIE [2-(1,2-diphenyl1H-indol-3-yl)ethanamine] Augments Pro-Inflammatory Cytokine Production in IL-1beta-Stimulated Primary Human Oral Cells. Int. J. Mol. Sci. 2018, 19, 1835. [CrossRef] [PubMed]

53. Rainsford, K.D. Profile and mechanisms of gastrointestinal and other side effects of nonsteroidal anti-inflammatory drugs (NSAIDs). Am. J. Med. 1999, 107, 27-35. [CrossRef]

54. Pihlstrom, B.L.; Michalowicz, B.S.; Johnson, N.W. Periodontal diseases. Lancet 2005, 366, $1809-1820$. [CrossRef]

55. Walker, C.B. The acquisition of antibiotic resistance in the periodontal microflora. Periodontology 2000 1996, 10, 79-88. [CrossRef] [PubMed]

56. Netuschil, L.; Weiger, R.; Preisler, R.; Brecx, M. Plaque bacteria counts and vitality during chlorhexidine, meridol and listerine mouthrinses. Eur. J. Oral Sci. 1995, 103, 355-361. [CrossRef] [PubMed]

57. Jorgensen, M.G.; Slots, J. Practical antimicrobial periodontal therapy. Compend. Contin. Educ. Dent. 2000, 21, 111-114. [PubMed]

58. Moro, M.G.; Silveira Souto, M.L.; Franco, G.C.N.; Holzhausen, M.; Pannuti, C.M. Efficacy of local phytotherapy in the nonsurgical treatment of periodontal disease: A systematic review. J. Periodontal Res. 2018, 53, 288-297. [CrossRef] [PubMed]

59. Rafieian-Kopaei, M.; Baradaran, A.; Rafieian, M. Plants antioxidants: From laboratory to clinic. J. Nephropathol. 2013, 2, 152-153. [CrossRef] [PubMed]

60. Shirzad, H.; Shahrani, M.; Rafieian-Kopaei, M. Comparison of morphine and tramadol effects on phagocytic activity of mice peritoneal phagocytes in vivo. Int. Immunopharmacol. 2009, 9, 968-970. [CrossRef] [PubMed]

61. Shirzad, H.; Taji, F.; Rafieian-Kopaei, M. Correlation between antioxidant activity of garlic extracts and WEHI-164 fibrosarcoma tumor growth in BALB/c mice. J. Med. Food 2011, 14, 969-974. [CrossRef] [PubMed]

62. Pistollato, F.; Giampieri, F.; Battino, M. The use of plant-derived bioactive compounds to target cancer stem cells and modulate tumor microenvironment. Food Chem. Toxicol. 2015, 75, 58-70. [CrossRef] [PubMed]

63. Dhiman, A.; Nanda, A.; Ahmad, S. A recent update in research on the antihepatotoxic potential of medicinal plants. Zhong Xi Yi Jie He Xue Bao 2012, 10, 117-127. [CrossRef] [PubMed]

64. Rafieian-Kopaei, M.; Nasri, H. Ginger and diabetic nephropathy. J. Renal Inj. Prev. 2013, 2, 9-10. [PubMed]

65. Beladi Mousavi, S.S.; Nasri, H.; Rafieian-Kopaei, M.; Tamadon, M.R. Metformin improves diabetic kidney disease. J. Nephropharmacol. 2012, 1, 1-2. [PubMed]

66. Gothai, S.; Ganesan, P.; Park, S.Y.; Fakurazi, S.; Choi, D.K.; Arulselvan, P. Natural Phyto-Bioactive Compounds for the Treatment of Type 2 Diabetes: Inflammation as a Target. Nutrients 2016, 8, 461. [CrossRef] [PubMed]

67. Asgary, S.; Sahebkar, A.; Afshani, M.R.; Keshvari, M.; Haghjooyjavanmard, S.; Rafieian-Kopaei, M. Clinical evaluation of blood pressure lowering, endothelial function improving, hypolipidemic and anti-inflammatory effects of pomegranate juice in hypertensive subjects. Phytother. Res. 2014, 28, 193-199. [CrossRef] [PubMed]

68. Samoilova, Z.; Muzyka, N.; Lepekhina, E.; Oktyabrsky, O.; Smirnova, G. Medicinal plant extracts can variously modify biofilm formation in Escherichia coli. Antonie Van Leeuwenhoek 2014, 105, 709-722. [CrossRef] [PubMed] 
69. Karki, R.; Jeon, E.R.; Kim, D.W. Magnoliae Cortex inhibits intimal thickening of carotid artery through modulation of proliferation and migration of vascular smooth muscle cells. Food Chem. Toxicol. 2012, 50, 634-640. [CrossRef] [PubMed]

70. Harokopakis, E.; Albzreh, M.H.; Haase, E.M.; Scannapieco, F.A.; Hajishengallis, G. Inhibition of proinflammatory activities of major periodontal pathogens by aqueous extracts from elder flower (Sambucus nigra). J. Periodontol. 2006, 77, 271-279. [CrossRef] [PubMed]

71. Kim, J.; Kim, C.S.; Lee, Y.M.; Sohn, E.; Jo, K.; Kim, J.S. Litsea japonica extract inhibits neuronal apoptosis and the accumulation of advanced glycation end products in the diabetic mouse retina. Mol. Med. Rep. 2015, 12, 1075-1081. [CrossRef] [PubMed]

72. Kim, J.; Kim, C.S.; Lee, I.S.; Lee, Y.M.; Sohn, E.; Jo, K.; Kim, J.H.; Kim, J.S. Extract of Litsea japonica ameliorates blood-retinal barrier breakdown in $\mathrm{db} / \mathrm{db}$ mice. Endocrine 2014, 46, 462-469. [CrossRef] [PubMed]

73. Ham, Y.M.; Ko, Y.J.; Song, S.M.; Kim, J.; Kim, K.N.; Yun, J.H.; Cho, J.H.; Ahn, G.; Yoon, W.J. Anti-inflammatory effect of litsenolide B2 isolated from Litsea japonica fruit via suppressing NF- $\mathrm{B}$ and MAPK pathways in LPS-induced RAW264.7 cells. J. Funct. Foods 2015, 13, 80-88. [CrossRef]

74. Yoon, W.J.; Kang, S.C.; Ham, Y.M.; Kim, K.N.; Yang, W.H.; Kim, H.J.; Park, S.Y.; Jung, Y.H. Antioxidative and anti-inflammatory activities of Litsea japonica leaves. J. Korean Soc. Appl. Biol. Chem. 2010, 53, 27-32. [CrossRef]

75. Min, B.S.; Lee, S.Y.; Kim, J.H.; Kwon, O.K.; Park, B.Y.; An, R.B.; Lee, J.K.; Moon, H.I.; Kim, T.J.; Kim, Y.H.; et al. Lactones from the leaves of Litsea japonica and their anti-complement activity. J. Nat. Prod. 2003, 66, 1388-1390. [CrossRef] [PubMed]

76. Ngo, Q.T.; Cao, T.Q.; Tran, P.L.; Kim, J.A.; Seo, S.T.; Kim, J.C.; Woo, M.H.; Lee, J.H.; Min, B.S. Lactones from the pericarps of Litsea japonica and their anti-inflammatory activities. Bioorg. Med. Chem. Lett. 2018, 28, 2109-2115. [CrossRef] [PubMed]

77. Somerman, M.J.; Archer, S.Y.; Imm, G.R.; Foster, R.A. A comparative study of human periodontal ligament cells and gingival fibroblasts in vitro. J. Dent. Res. 1988, 67, 66-70. [CrossRef] [PubMed]

78. Rampersad, S.N. Multiple applications of Alamar Blue as an indicator of metabolic function and cellular health in cell viability bioassays. Sensors 2012, 12, 12347-12360. [CrossRef] [PubMed] 